\title{
THE RELATIONSHIP BETWEEN DENTAL CARIES AND BODY MASS INDEX AMONG PRIMARY SCHOOL CHILDREN IN MAKKAH CITY
}

\author{
Alamri M. Fahad*, Alahmadi O. Abdulrahman*, AlGhamdi S. Badr*, \\ Alghamdi A. Essam ${ }^{* *}$, Alqarni S. Anas ${ }^{* * *}$, Alzahrani A. Raed ${ }^{* * * *}$ and Adel Fathi ${ }^{* * * * *}$
}

\begin{abstract}
Purpose: To evaluate the association between dental caries and body mass index (BMI) among a sample of male primary school children in Makkah city, Saudi Arabia.

Population and Methods: This is a cross-sectional study carried out on a sample of 548 6-12-years-old children in Makkah City, western region of Saudi Arabia. Cluster random sampling technique was applied to select students from public as well as private schools. All the subjects were examined by a single operator using a dmft (decayed, missing, filled primary teeth) and DMFT (decayed, missing, filled, permanent teeth) indices and BMI after obtaining the informed consent.

Results: The study included children with mean age $9.5 \pm 1.8$ years. Of the examined children, $91.2 \%$ had dental caries. Obese children represented $16.8 \%$ of the participants whereas underweight represented $11.6 \%$ of them. Caries prevalence in primary and permanent teeth among caries-affected children was $67.60 \%$ and $86.40 \%$ respectively. Underweight children exhibited the highest prevalence and severity of dental caries in both primary and permanent teeth. Correlation analysis showed significant negative relations with BMI, dmft $[\mathrm{r}=-0.627, \mathrm{p}<0.01]$ and DMFT $[\mathrm{r}=-0.205, \mathrm{p}<0.01]$.
\end{abstract}

Conclusions: Most of 6-12-years-old primary school children in Makkah had dental caries in both primary and permanent teeth. Underweight children were more likely to have dental caries in both primary and permanent teeth compared to children with other BMI categories.

KEY WORDS: Dental caries, Body mass index, Primary school children.

\footnotetext{
* Dental intern, College of Dentistry, Umm Al Qura University, Makkah, KSA.

** Medical Intern, College of Medicine, Umm Al Qura University, Makkah, KSA.

*** Senior Dental Student, College of Dentistry, Umm Al Qura University, Makkah, KSA.

$* * * *$ BDS, Ministry of Health, KSA.

***** Lecturer of Pediatric Dentistry, Faculty of Dental Medicine, Al-Azhar University, Cairo, Egypt. Assistant

Professor of Pediatric Dentistry, College of Dentistry, Umm Al Qura University, Makkah, KSA.
} 


\section{INTRODUCTION}

Dental caries and obesity are critical health problems worldwide and have been associated with a great number of negative health outcomes ${ }^{[1,2]}$. Dental caries is the most common infectious and transmissible childhood disease worldwide. It still affects many school children, despite all the efforts made in prevention programs. If caries is untreated, it may lead to discomfort, pain and finally loss of teeth. Furthermore, untreated dental caries affects general health, quality of life, productivity, developmental milestones and educational performance of children ${ }^{[3-7]}$.

Analyzing and integrating several causative factors such as fluoride, microbial plaque, diet, salivary activity, social and life style related behavioral factors could evaluate the risk of dental caries ${ }^{[8,9]}$. Accordingly, for caries prevention and maintenance of oral health, several factors such as food low in fermentable carbohydrates, oral hygiene techniques, fluoride supplements, in addition to regular dental examinations have to be taken into consideration. Different preventive programs during the last decades lead to a significant decrease in dental caries, particularly in children ${ }^{[10-12]}$.

Obesity is one of major public health problems in modern societies. Children are amongst the fastest growing group of the overweight and obese population. Childhood obesity is verified to be associated with numerous risk factors as cardiovascular diseases, type 2 diabetes mellitus and other chronic diseases ${ }^{[13-16]}$.

Childhood obesity and overweight are mainly due to intake of low-density foods instead of vegetables and fruits and also due to high fat and high carbohydrate foods. Moreover, sedentary activities and certain socioeconomic factors are involved ${ }^{[17,18]}$.

The prevalence of obesity and overweight among children and adolescents in some of the developed countries had increased over the last four decades. The percentage of obesity and overweight among Canadian children has increased significantly ${ }^{[19]}$. In Australia, National Health Survey data 2014-15 revealed that childhood obesity and overweight increased from $25.7 \%$ in $2011-12$ to $27.4 \%$ in 2014 $15^{[20]}$. The prevalence of obesity among German school children increased from $1.8 \%$ in 1982 to $2.8 \%$ in $1997^{[21]}$. In Saudi Arabia, a noticeable rise in childhood obesity level over the past two decades was evident. The prevalence of obesity in Saudi Arabia was significantly higher in 2013 than $2008^{[22-25]}$.

Body mass index (BMI) is the most commonly used measure for revealing the prevalence of obesity and overweight. It measures height for weight, which is frequently used to categorize underweight, overweight, and obese individuals ${ }^{[26]}$. Among children and teenagers, the amount of body fat differs between boys and girls. It also changes as the body grows. Hence, BMI assessments for children and teenagers take the growth and gender differences into account. These specific BMI values for children are referred to as "BMI-for-age." [27]

The association between dental caries and obesity in children has been evaluated in several studies; however, the results have always been different and generally contradictory ${ }^{[28-34]}$.

Whereas, malnutrition manifested by obesity or underweight are common problems among children in developing countries and KSA society is not an exception. Also, dental caries is very prevalent despite efforts done to reduce its burden. There have been little researches documented in literature in this part of Saudi Arabia assessing the prevalence of dental caries in relation to BMI. Therefore, the current study was designed to assess the association between dental caries and BMI among 6-12-yearsold primary school children in Makkah City. 


\section{MATERIALS AND METHODS}

\section{Study sample}

The present cross-sectional study was carried out on a group of 6-12-years-old children in Makkah City in the western region of Saudi Arabia. The sample consisted of 548 primary school children. Public as well as private schools were randomly chosen, and 6-12-years-old children were randomly selected from the data of the school records using the cluster random sampling procedure.

The exclusion criteria included: pupils who are physically challenged, those with systemic illness and uncooperative children. Pupils with dentofacial deformities or any syndrome were also excluded.

\section{Data collection procedure}

All subjects were examined by a single operator using a dmft (decayed, missing, filled primary teeth) and DMFT (decayed, missing, filled, permanent teeth) indices and body mass index (BMI) after obtaining the informed consent.

A non-invasive dental examination was performed using mirror, No. 23 explorer and cotton rolls, with optimal illumination of the oral cavity. Determination of carious lesions was carried out visually without radiographic examination. Cavities and significant discolorations around the restorations were diagnosed as carious lesions. The clinical examination of dental caries for all participants constituting the sample was entirely done by a single investigator who was trained and calibrated for recording the WHO Oral Health Performa (WHO, 1997) for oral diseases ${ }^{[35]}$.

The dmft was categorized according to the caries severity, based on previously suggested scores: dmft $0=$ no caries; dmft 1 to $5=$ low severity; and $\mathrm{dmft} \geq 6=$ high severity ${ }^{[36-38]}$. While, the DMFT index was categorized based on the severity scale to indicate very low prevalence with DMFT 0 to 1.1; low prevalence 1.2 to 2.6 ; moderate prevalence
2.7 to 4.4 ; high prevalence 4.5 to 6.5 ; and very high prevalence when the DMFT is greater than or equal to $6.6^{[39,40]}$.

The height and weight of each child were recorded in a separate sheet. BMI was calculated according to the following formula: $\mathrm{BMI}=$ Weight in $\mathrm{kg}$ Height in $\mathrm{m}^{2}$.

The value obtained was then plotted on age and gender-specific percentiles given by the Centers for Disease Control and Prevention (CDC $)^{[41]}$. Children were accordingly categorized into four groups based on their BMI percentiles as follows:

- Underweight group children with BMI-for-age $<5^{\text {th }}$ percentile.

- Normal group children with BMI-for-age $\geq 5^{\text {th }}$ percentile and $<85^{\text {th }}$ percentile.

- Overweight group children with BMI-for-age $\geq 85^{\text {th }}$ percentile and $<95^{\text {th }}$ percentile.

- Obese group children with $\mathrm{BMI} \geq 95^{\text {th }}$ percentile.

\section{Data analysis}

Analysis of the data was compiled by a descriptive method using frequency and percentage. Statistical analysis was performed by the computer program SPSS (Statistical Package for Social Sciences, version 22.0). Chi-square test was used to measure the association between categorical variables and p-value less than 0.05 was considered statistically significant.

\section{Ethical considerations}

Permission to conduct the survey in the selected schools was obtained from the respective school authorities and was planned over a period of eight weeks. To respect the participant's autonomous choices and integrity, they were informed verbally that the study is voluntary, and if somebody changed his mind before or while conducting the examination, he was allowed to discontinue the participation. 
Parent/child was given a written consent following explanation of the information sheet. Research reports and manuscripts for publication contained no material that allowed identification of individual participants. The local research ethics committee was approached for approval to undertake the study.

\section{RESULTS}

The current study included 548 school children, their age ranged between 6 and 12 years with a mean and $( \pm \mathrm{SD})$ of $9.5 \pm 1.8$ years. Out of the 548 examined children, $500(91.2 \%)$ were caries-affected. Distribution of caries prevalence with respect to age is presented in table 1 . The means for the $\mathrm{dmft}$ and DMFT indices in cariesaffected children were $3.43 \pm 3.24$ and $1.69 \pm 1.14$ respectively. Body mass index (BMI) distribution showed that obese children represented $16.8 \%$ of the participants whereas overweight represented $10.4 \%$, figure 1 .

TABLE (1) Distribution of caries prevalence in relation to children's age.

\begin{tabular}{|c|c|c|}
\hline $\begin{array}{c}\text { Age } \\
(\text { Years })\end{array}$ & No. & $\%$ \\
\hline $6(\mathrm{n}=41)$ & 36 & 87.80 \\
\hline $7(\mathrm{n}=44)$ & 41 & 93.18 \\
\hline $8(\mathrm{n}=88)$ & 82 & 93.18 \\
\hline $9(\mathrm{n}=81)$ & 74 & 91.36 \\
\hline $10(\mathrm{n}=103)$ & 94 & 91.26 \\
\hline $11(\mathrm{n}=106)$ & 96 & 90.57 \\
\hline $12(\mathrm{n}=85)$ & 77 & 90.59 \\
\hline Total $(548)$ & 500 & 91.24 \\
\hline
\end{tabular}

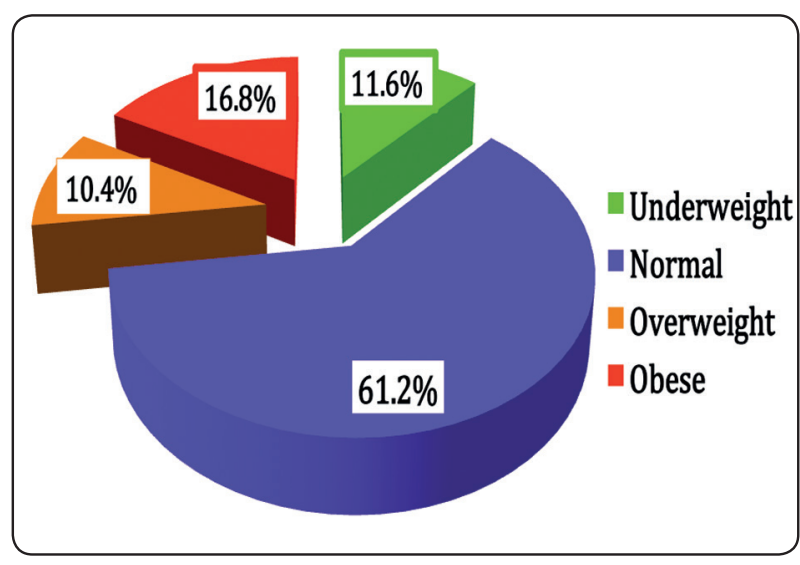

Fig. (1) Distribution of school children according to BMI categories.

The relation between age and BMI categories of caries-affected children is presented in table 2 . Obesity was highest among children aged 12 years $(31.2 \%)$, lower in those aged 10 years $(21.3 \%)$ and lowest among 6-years-old children (5.5\%). Overweight was highest among children aged 9 years $(18.9 \%)$ and lowest among those aged 6 years (2.8\%). Most underweight children (16.7\%) were 6-years-old. The association between children's ages and BMI categories was statistically significant $(\mathrm{p}=0.008)$.

TABLE (2) Age and BMI categories distribution among caries-affected children

\begin{tabular}{|c|c|c|c|c|c|c|c|c|}
\hline $\begin{array}{c}\text { Age } \\
\text { (Years) }\end{array}$ & \multicolumn{2}{|c|}{$\begin{array}{c}\text { Under } \\
\text { weight }\end{array}$} & \multicolumn{2}{|c|}{ Normal } & \multicolumn{2}{c|}{$\begin{array}{c}\text { Over } \\
\text { weight }\end{array}$} & \multicolumn{2}{|c|}{ Obese } \\
\hline & No. & $\%$ & No. & $\%$ & No. & $\%$ & No. & $\%$ \\
\hline 6 & 6 & 16.7 & 27 & 75.0 & 1 & 2.8 & 2 & 5.5 \\
\hline 7 & 6 & 14.6 & 29 & 70.7 & 2 & 4.9 & 4 & 9.8 \\
\hline 8 & 10 & 12.2 & 50 & 61.0 & 8 & 9.7 & 14 & 17.1 \\
\hline 9 & 5 & 6.7 & 48 & 64.9 & 14 & 18.9 & 7 & 9.5 \\
\hline 10 & 14 & 14.9 & 53 & 56.4 & 7 & 7.4 & 20 & 21.3 \\
\hline 11 & 11 & 11.5 & 61 & 63.5 & 11 & 11.5 & 13 & 13.5 \\
\hline 12 & 6 & 7.8 & 38 & 49.4 & 9 & 11.7 & 24 & 31.2 \\
\hline$X^{2}=35.50, \mathrm{p}=0.008$ & & & \\
\hline
\end{tabular}


The prevalence of dental caries in primary teeth among caries-affected children was $67.60 \%$, figure 2 . The highest prevalence was reported among children aged 6 years $(100 \%)$, whereas the lowest prevalence was reported among those aged 12 years $(18.18 \%)$. The difference was statistically significant, $\mathrm{p}<0.001$, table 3 .

The prevalence of permanent teeth caries among affected children was $86.40 \%$. The highest prevalence was reported among children aged 12 years $(98.70 \%)$ whereas the lowest prevalence was reported among 6-years-old children (5.56\%). The difference was statistically significant, $\mathrm{p}<0.001$, figure 3 and table 3.

TABLE (3) Primary and permanent teeth caries prevalence according to age

\begin{tabular}{|c|c|c|c|c|}
\hline \multirow{2}{*}{ Age } & \multicolumn{2}{|c|}{ Primary teeth } & \multicolumn{2}{c|}{ Permanent teeth } \\
\cline { 2 - 5 } & $\mathrm{N}$ & $\%$ & $\mathrm{~N}$ & $\%$ \\
\hline $6(\mathrm{n}=36)$ & 36 & 100.00 & 2 & 5.56 \\
\hline $7(\mathrm{n}=41)$ & 38 & 92.68 & 20 & 48.78 \\
\hline $8(\mathrm{n}=82)$ & 73 & 89.02 & 79 & 96.34 \\
\hline $9(\mathrm{n}=74)$ & 56 & 75.68 & 71 & 95.95 \\
\hline $10(\mathrm{n}=94)$ & 75 & 79.79 & 91 & 96.81 \\
\hline $11(\mathrm{n}=96)$ & 46 & 47.92 & 93 & 96.88 \\
\hline \multirow{2}{*}{$12(\mathrm{n}=77)$} & 14 & 18.18 & 76 & 98.70 \\
\cline { 2 - 5 } & \multicolumn{2}{|c|}{$X^{2}=325.99, \mathrm{p}<0.001$} & $X^{2}=42.497, \mathrm{p}<0.001$ \\
\hline
\end{tabular}

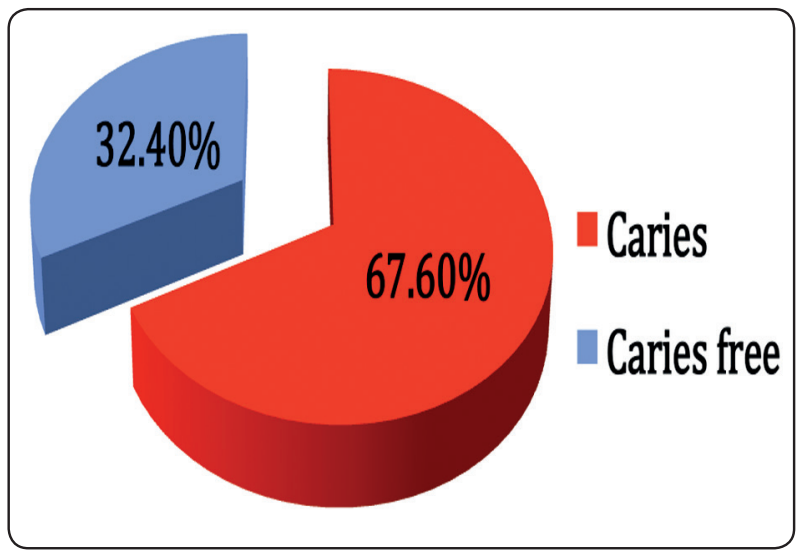

Fig. (2) Prevalence of primary teeth caries among cariesaffected children
Underweight children reported the highest prevalence of primary teeth caries $(94.82 \%)$ and the lowest prevalence was reported among obese children $(30.95 \%)$. The association between BMI and the prevalence of primary teeth caries was statistically significant, $\mathrm{p}<0.001$, table 4 .

Normal weight children reported the lowest prevalence of permanent teeth caries $(81.70 \%)$ whereas the highest prevalence was reported among overweight children (96.15\%). The association between BMI and prevalence of permanent teeth caries was statistically significant, $p>0.001$, table 4 .

TABLE (4) Primary and permanent teeth caries prevalence according to BMI categories

\begin{tabular}{|c|c|c|c|c|}
\hline \multirow{2}{*}{$\begin{array}{c}\text { BMI } \\
\text { categories }\end{array}$} & \multicolumn{2}{|c|}{ Primary teeth } & \multicolumn{2}{c|}{ Permanent teeth } \\
\cline { 2 - 5 } & $\mathrm{N}$ & $\%$ & $\mathrm{~N}$ & $\%$ \\
\hline $\begin{array}{c}\text { Under weight } \\
(\mathrm{n}=58)\end{array}$ & 55 & 94.82 & 52 & 89.66 \\
\hline $\begin{array}{c}\text { Normal } \\
(\mathrm{n}=306)\end{array}$ & 228 & 74.50 & 250 & 81.70 \\
\hline $\begin{array}{c}\text { Over weight } \\
(\mathrm{n}=52)\end{array}$ & 29 & 55.77 & 50 & 96.15 \\
\hline Obese (n=84) & 26 & 30.95 & 80 & 95.24 \\
\hline & $X^{2}=107.75, \mathrm{p}=0.001$ & $X^{2}=160.85, \mathrm{p}=0.001$ \\
\hline
\end{tabular}

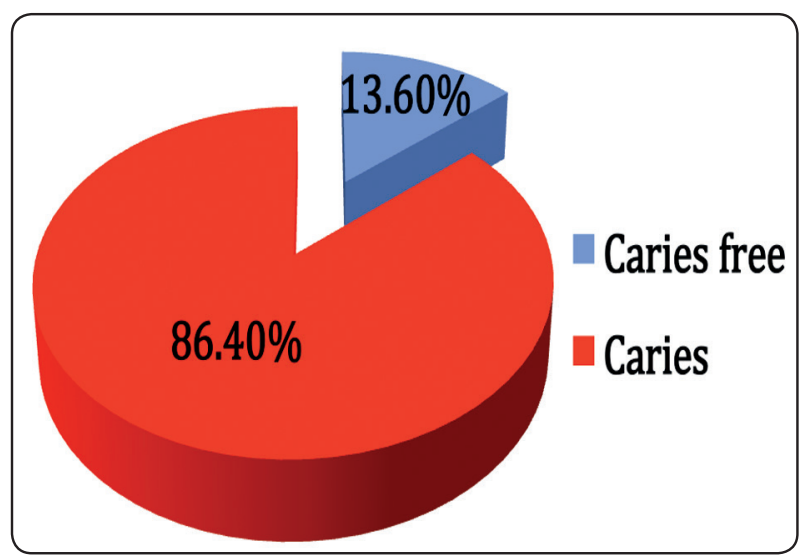

Fig. (3) Prevalence of permanent teeth caries among cariesaffected children 
The means for $\mathrm{dmft}$ and DMFT indices concerning children's ages and BMI categories are presented in table 5 .

Regarding caries severity of primary teeth, high severity was reported among children aged 6 years $(72.22 \%)$, followed by those aged 7 years $(60.98 \%)$ whereas the percentage of high severity was zero among children aged 11 and 12 years. The difference was statistically significant, $\mathrm{p}<0.001$ as shown in table 6.

High caries severity of primary teeth was reported among underweight children (56.90\%) than other categories (normal " $28.43 \%$ ", overweight " $25.00 \%$ " and obese " $4.76 \%$ "). The difference was statistically significant, $\mathrm{p}<0.001$, table 6 .

Regarding caries severity of permanent teeth, none of them reported neither very high nor high caries severity. Moderate severity was reported among children aged 8-12 years with the highest scores, $37.50 \%$ among children aged 11 years and $65.52 \%$ among underweight children. Very low caries severity, $100 \%$ and $76.19 \%$, were reported among 6-years-old and obese children respectively. The difference was statistically significant, $p<0.001$, tables 7 .

TABLE (5) Distribution of dental caries (primary dentition: dmft index; permanent dentition: DMFT index) relative to Age and BMI categories

\begin{tabular}{|c|c|c|c|}
\hline & & \multicolumn{2}{|c|}{ Mean value $( \pm \mathrm{SD})$} \\
\hline \multirow{8}{*}{ 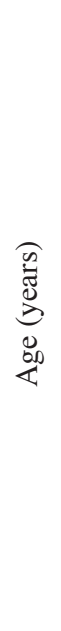 } & & $\mathrm{dmft}$ & DMFT \\
\hline & $6(\mathrm{n}=36)$ & $6.86( \pm 2.36)$ & $0.06( \pm 0.23)$ \\
\hline & $7(\mathrm{n}=41)$ & $6.15( \pm 2.97)$ & $0.37( \pm 0.70)$ \\
\hline & $8(\mathrm{n}=82)$ & $5.93( \pm 3.22)$ & $1.68( \pm 0.95)$ \\
\hline & $9(\mathrm{n}=74)$ & $3.91( \pm 2.97)$ & $1.64( \pm 0.75)$ \\
\hline & $10(\mathrm{n}=94)$ & $3.45( \pm 2.22)$ & $2.00( \pm 1.17)$ \\
\hline & $11(n=96)$ & $0.93( \pm 1.10)$ & $2.30( \pm 1.08)$ \\
\hline & $12(\mathrm{n}=77)$ & $0.35( \pm 0.76)$ & $2.09( \pm 0.92)$ \\
\hline \multirow{4}{*}{ 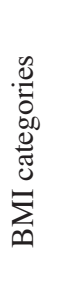 } & Underweight $(\mathrm{n}=58)$ & $6.88( \pm 3.83)$ & $2.91( \pm 1.34)$ \\
\hline & Normal $(n=306)$ & $3.50( \pm 2.81)$ & $1.60( \pm 1.13)$ \\
\hline & Overweight $(\mathrm{n}=52)$ & $2.85( \pm 3.05)$ & $1.65( \pm 0.76)$ \\
\hline & Obese $(n=84)$ & $1.14( \pm 2.10)$ & $1.20( \pm 0.53)$ \\
\hline
\end{tabular}


TABLE (6) Caries severity of primary teeth according to age and BMI categories

\begin{tabular}{|c|c|c|c|c|c|c|c|c|}
\hline & & \multicolumn{2}{|c|}{$\begin{array}{c}\text { No caries } \\
(\mathrm{dmf}=0) \\
\mathrm{N}=162\end{array}$} & \multicolumn{2}{|c|}{$\begin{array}{l}\text { Low severity } \\
\qquad \begin{array}{c}(\mathrm{dmf} 1-5) \\
\mathrm{N}=201\end{array}\end{array}$} & \multicolumn{2}{|c|}{$\begin{array}{l}\text { High severity } \\
\qquad \begin{array}{c}(\mathrm{dmf} \geq 6) \\
\mathrm{N}=137\end{array}\end{array}$} & \\
\hline & & $\mathrm{N}$ & $\%$ & $\mathrm{~N}$ & $\%$ & $\mathrm{~N}$ & $\%$ & \\
\hline \multirow{7}{*}{ 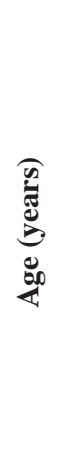 } & $6(n=36)$ & 0 & 0.00 & 10 & 27.78 & 26 & 72.22 & \multirow{7}{*}{$\begin{array}{c}X^{2}=441.00 \\
\mathrm{p}<0.001\end{array}$} \\
\hline & $7(n=41)$ & 3 & 7.32 & 13 & 31.71 & 25 & 60.98 & \\
\hline & $8(\mathrm{n}=82)$ & 9 & 10.98 & 25 & 30.49 & 48 & 58.54 & \\
\hline & $9(n=74)$ & 18 & 24.32 & 33 & 44.59 & 23 & 31.08 & \\
\hline & $10(n=94)$ & 19 & 20.21 & 60 & 63.83 & 15 & 15.96 & \\
\hline & $11(\mathrm{n}=96)$ & 50 & 52.08 & 46 & 47.92 & 0 & 0.00 & \\
\hline & $12(\mathrm{n}=77)$ & 63 & 81.82 & 14 & 18.18 & 0 & 0.00 & \\
\hline \multirow{4}{*}{ 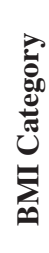 } & Under weight $(\mathrm{n}=58)$ & 0 & 0.00 & 25 & 43.10 & 33 & 56.90 & \multirow{4}{*}{$\begin{array}{c}X^{2}=237.56, \\
p<0.001\end{array}$} \\
\hline & Normal (n=306) & 78 & 25.49 & 141 & 46.08 & 87 & 28.43 & \\
\hline & Over weight $(\mathrm{n}=52)$ & 24 & 46.15 & 15 & 28.85 & 13 & 25.00 & \\
\hline & Obese $(n=84)$ & 60 & 71.43 & 20 & 23.81 & 4 & 4.76 & \\
\hline
\end{tabular}

TABLE (7) Caries severity of permanent teeth according to age and BMI categories

\begin{tabular}{|c|c|c|c|c|c|c|c|c|}
\hline \multirow{9}{*}{ 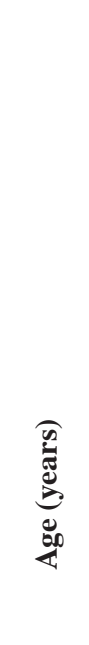 } & & \multicolumn{2}{|c|}{$\begin{array}{c}\text { Very low } \\
\text { (DMFT 0-1.1) } \\
\mathrm{N}=238\end{array}$} & \multicolumn{2}{|c|}{$\begin{array}{c}\text { Low } \\
\text { (DMFT 1.2-2.6) } \\
\mathrm{N}=163\end{array}$} & \multicolumn{2}{|c|}{$\begin{array}{c}\text { Moderate } \\
\text { (DMFT 2.7-4.4) } \\
\text { N=99 }\end{array}$} & \\
\hline & & $\mathrm{N}$ & $\%$ & $\mathrm{~N}$ & $\%$ & $\mathrm{~N}$ & $\%$ & \\
\hline & $6(n=36)$ & 36 & 100 & 0 & 0.00 & 0 & 0.00 & \multirow{7}{*}{$\begin{array}{c}X^{2}=438.58, \\
\mathrm{p}<0.001\end{array}$} \\
\hline & $7(n=41)$ & 36 & 87.80 & 5 & 12.20 & 0 & 0.00 & \\
\hline & $8(n=82)$ & 42 & 51.22 & 27 & 32.93 & 13 & 15.85 & \\
\hline & $9(n=74)$ & 37 & 50.00 & 29 & 39.19 & 8 & 10.81 & \\
\hline & $10(n=94)$ & 41 & 43.62 & 29 & 30.85 & 24 & 25.53 & \\
\hline & $11(\mathrm{n}=96)$ & 26 & 27.08 & 34 & 35.42 & 36 & 37.50 & \\
\hline & $12(\mathrm{n}=77)$ & 20 & 25.97 & 39 & 50.65 & 18 & 23.38 & \\
\hline \multirow{4}{*}{ 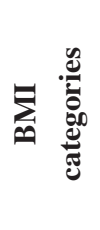 } & Under weight $(n=58)$ & 8 & 13.79 & 12 & 20.70 & 38 & 65.52 & \multirow{4}{*}{$\begin{array}{c}X^{2}=185.95, \\
\mathrm{p}=0.001\end{array}$} \\
\hline & Normal $(n=306)$ & 144 & 47.06 & 107 & 34.97 & 55 & 17.97 & \\
\hline & Over weight $(\mathrm{n}=52)$ & 22 & 42.31 & 25 & 48.08 & 5 & 9.62 & \\
\hline & Obese $(n=84)$ & 64 & 76.19 & 19 & 22.62 & 1 & 1.19 & \\
\hline
\end{tabular}


Correlation analysis showed that BMI had a negative correlation with both $\mathrm{dmft}[\mathrm{r}=-0.627, \mathrm{p}<$ $0.01]$ and DMFT $[r=-0.205, p<0.01]$, table 8 .

TABLE (8) Correlation between BMI, dmft and DMFT

\begin{tabular}{|c|c|c|c|c|}
\hline & & $\mathrm{dmft}$ & DMFT & BMI \\
\hline & $\begin{array}{l}\text { Pearson } \\
\text { Correlation }\end{array}$ & 1 & $-.100(*)$ & $-.627(* *)$ \\
\hline$\Xi$ & Sig. (2-tailed) & & .026 & .000 \\
\hline & $\mathrm{N}$ & 500 & 500 & 500 \\
\hline 一 & $\begin{array}{l}\text { Pearson } \\
\text { Correlation }\end{array}$ & $-.100(*)$ & 1 & $-.205(* *)$ \\
\hline$\sum^{E}$ & Sig. (2-tailed) & .026 & . & .000 \\
\hline & $\mathrm{N}$ & 500 & 500 & 500 \\
\hline & $\begin{array}{l}\text { Pearson } \\
\text { Correlation }\end{array}$ & $-.627(* *)$ & $-.205(* *)$ & 1 \\
\hline$\sum_{\infty}$ & Sig. (2-tailed) & .000 & .000 & \\
\hline & $\mathrm{N}$ & 500 & 500 & 500 \\
\hline
\end{tabular}

* Correlation is significant at the 0.05 level (2-tailed).

** Correlation is significant at the 0.01 level (2-tailed).

\section{DISCUSSION}

Worldwide dental caries and obesity represent public health problems among children as they have been associated with adverse health outcomes ${ }^{[1}$, 42, 43]. This study was thus prompted to investigate the relationship which exists between dental caries and body mass index (BMI) among Saudi primary school children in Makkah city.

Of the examined 548 children, $91.2 \%$ had dental caries. This observation is consistent with a study carried out on 6-15-years-old school children in Jazan, Saudi Arabia, where caries prevalence was 91.3\% ${ }^{[44]}$. Whereas, in Dammam, caries prevalence was $73 \%$ among school children aged 6-12 years ${ }^{[45]}$.
The World Health Organization (WHO) and World Dental Federation (FDI) oral health goals to be achieved by the year 2000 reported that prevalence of dental caries in 5-6-year-olds should be less than $50 \%{ }^{[46]}$. The results of our study revealed that approximately $88 \%$ of 6 -years-old children were suffering from dental caries, and this is considered quite high compared with the WHO and FDI oral health goals ${ }^{[46]}$.

In the current study, the mean dmft index in caries-affected children was nearly consistent with Farooqi et al., (2015) ${ }^{[45]}$ who reported 3.66 \pm 3.13 mean dmft value among Saudi children. While the mean DMFT index in caries-affected children was $1.69 \pm 1.14$, which confirms the data of a previous study on the caries prevalence in 7-11-years-old Saudi primary school children in Riyadh where the DMFT index was $1.6 \pm 1.5^{[47]}$.

Statistical analysis of the results revealed that BMI has a negative correlation with both $\mathrm{dmft}$ and DMFT, where high caries severity of both primary and permanent teeth was reported with underweight children. These findings reveal a significant association between dental caries severity and underweight in contrast to what has been reported in previous studies where a significant association between caries and obesity was reported ${ }^{[2,32,48]}$.

However, the findings of the current study are in agreement with a previous study where an inverse association between dental caries severity and BMI among children aged 6-11 years was observed ${ }^{[49]}$. Also, other studies reported an inverse relationship between dental caries experience and BMI ${ }^{[50,51]}$. On the other hand, several studies ${ }^{[29,52-54]}$ revealed no significant association between dental caries experience and BMI.

It has been documented that in the developing countries, including Saudi Arabia, young population suffers from a dual sequelae of malnutrition in the form of obesity and underweight ${ }^{[55]}$. This cannot be explained by defective food supply alone but other 
factors such as maternal educational level, family size and economic class influence the nutritional status of children.

Regarding the association between underweight and severity of dental caries observed in the present study, it has been reported that disturbed sleep as a result of pain can affect glucosteroid production in the body, which impairs the growth ${ }^{[56]}$. Another possible mechanism for the effect of dental caries on growth of children could be related to chronic inflammation from pulpitis and dental abscess. Both of these conditions change the metabolic pathways resulting in increased cytokine production ${ }^{[57-59]}$.

The association between dental caries and underweight observed in the present study could be explained on the bases that severe dental caries can affect individuals by causing dietary restrictions via difficulty in chewing, possibly compromising their nutritional status and well-being ${ }^{[56,60]}$. It is also known that feeding problems have a great potential effect on the health status, because of which the dentition and oral mucosa are affected ${ }^{[57]}$.

Among the important limitations of the present study is neglecting the specific dietary habits such as intake of sugar-sweetened drinks, frequency of sugar intake, and frequency of food intake between meals as well as dental hygiene details in analysis, which are considered as risk factors for both dental caries and childhood weight status. Moreover, caries detection was carried out visually without radiographic examination.

\section{CONCLUSION}

Majority of primary school children in Makkah city had dental caries in both primary and permanent teeth. More than one-quarter of them were either overweight or obese whereas more than $11 \%$ were underweight. The prevalence of dental caries is still high considering the World Health Organization and World Dental Federation future oral health goals. Underweight students were more likely to have dental caries in both primary and permanent teeth compared to other BMI groups.

\section{RECOMMENDATIONS}

Oral health education for mothers and their children at health centers and schools is recommended. Encourage physical training and promote healthy eating pattern among primary school children. Encourage mothers to attend regularly with their children to dentists for early detection of dental caries and to be advised for proper dental hygiene. BMI should be estimated and included in the standard case history of children, as it can help in detection of potential health problems in children. Carry out further research including in depth investigation of eating pattern and oral hygiene practice.

\section{CONFLICT OF INTEREST}

Authors declare no conflict of interest.

\section{REFERENCES}

1. Hedge AM, Sharma A. Genetic sensitivity to 6-n-propylthiouracil (PROP) as a screening tool for obesity and dental caries in children. J Clin Pediatr Dent. 2008; 33 (2): 107-11.

2. Yao Y, Ren X, Song X, He L, Jin Y, Chen Y, Lu W, Guo D, Ding L, Tang H, Wei N, Qiu S, Li C. The relationship between dental caries and obesity among primary school children aged 5 to 14 years. Nutr Hosp. 2014; 30(1): 60-5.

3. Koranyi K, Rasnake LK, Tarnowski KJ. Nursing bottle weaning and prevention of dental caries: a survey of pediatricians. Pediatr Dent. 1991; 13(1): 32-4.

4. Caufield PW. Dental caries: an infectious and transmissible disease where have we been and where are we going? $\mathrm{N} \mathrm{Y}$ State Dent J. 2005; 71(2): 23-7.

5. Khan SQ. Dental caries in Arab League countries: a systematic review and meta-analysis. Int Dent J. 2014; 64(4): 173-80.

6. de Paula JS, Ambrosano GM, Mialhe FL. Oral Disorders, Socioenvironmental Factors and Subjective Perception Impact on Children's School Performance. Oral Health Prev Dent. 2015; 13(3): 219-26. 
7. Kragt L, van der Tas JT, Moll HA, Elfrink ME, Jaddoe VW, Wolvius EB, Ongkosuwito EM. Early Caries Predicts Low Oral Health-Related Quality of Life at a Later Age. Caries Res. 2016; 50(5): 471-479.

8. Reich E, Lussi A, Newbrun E. Caries-risk assessment. Int Dent J. 1999; 49 (1): 15-26.

9. Yorty JS, Walls AT, Wearden S. Caries risk assessment/ treatment programs in U.S. dental schools: an eleven-year follow-up. J Dent Educ. 2011; 75(1): 62-7.

10. Moynihan P, Petersen PE. Diet, nutrition and the prevention of dental diseases. Public Health Nutr. 2004; 7(1A): 201-26.

11. Tai BJ, Jiang H, Du MQ, Peng B. Assessing the effectiveness of a school-based oral health promotion programme in Yichang City, China. Community Dent Oral Epidemiol. 2009; 37(5): 391-8.

12. Achembong LN, Kranz AM, Rozier RG. Office-based preventive dental program and statewide trends in dental caries. Pediatrics. 2014; 133(4): e827-34.

13. Rosario AS, Kurth BM, Stolzenberg H, Ellert U, Neuhauser $\mathrm{H}$. Body mass index percentiles for children and adolescents in Germany based on a nationally representative sample (KiGGS 2003-2006). Eur J Clin Nutr. 2010; 64(4): 341-9.

14. Ogden CL, Carroll MD, Kit BK, Flegal KM. Prevalence of obesity and trends in body mass index among US children and adolescents, 1999-2010. JAMA. 2012; 307(5): 483-90.

15. Xue Y, Gao M, Gao Y. Childhood type 2 diabetes: Risks and complications. Exp Ther Med. 2016; 12(4): 2367-70.

16. Aranceta-Bartrina J, Pérez-Rodrigo C. Determinants of childhood obesity: ANIBES study. Nutr Hosp. 2016; 33 Suppl 4: 339.

17. Ebbeling CB, Pawlak DB, Ludwig DS. Childhood obesity: public-health crisis, common sense cure. Lancet. 2002; 360 (9331): 473-82.

18. Gupta N, Goel K, Shah P, Misra A. Childhood obesity in developing countries: epidemiology, determinants, and prevention. Endocr. Rev. 2012; 33(1): 48-70.

19. Rao DP, Kropac E, Do MT, Roberts KC, Jayaraman GC. Childhood overweight and obesity trends in Canada. Health Promot Chronic Dis Prev Can. 2016; 36(9): 194-8.

20. ABS (2015) 4364.0.55.001-National Health Survey: First Results, 2014-15.

21. Kalies H, Lenz J, von Kries R. Prevalence of overweight and obesity and trends in body mass index in German pre-school children, 1982-1997. Int J Obes Relat Metab Disord. 2002; 26(9): 1211-7.

22. Abalkhail B. Overweight and obesity among Saudi Arabian children and adolescents between 1994 and 2000. East Mediterr Health J. 2002 Jul-Sep;8(4-5): 470-9.

23. Al-Hazzaa HM. Rising trends in BMI of Saudi adolescents: evidence from three national cross sectional studies. Asia Pac J Clin Nutr. 2007; 16(3): 462-6.

24. Al-Hazzaa HM. Prevalence and trends in obesity among school boys in Central Saudi Arabia between 1988 and 2005. Saudi Med J. 2007; 28(10): 1569-74.

25. Al-Daghri NM, Aljohani NJ, Al-Attas OS, Al-Saleh Y, Alnaami AM, Sabico S, Amer OE, Alharbi M, Kumar S, Alokail MS. Comparisons in childhood obesity and cardiometabolic risk factors among urban Saudi Arab adolescents in 2008 and 2013. Child Care Health Dev. 2016; 42(5): 652-7.

26. Aluckal E, Anzil K, Baby M, George EK, Lakshmanan S, Chikkanna S. Association between Body Mass Index and Dental Caries among Anganwadi Children of Belgaum City, India. J Contemp Dent Pract. 2016; 17(10): 844-8.

27. Macek MD, Mitola DJ. Exploring the association between overweight and dental caries among US children. Pediatr Dent. 2006; 28(4): 375-80.

28. Moreira PV, Rosenblatt A, Severo AM. Prevalence of dental caries in obese and normal-weight Brazilian adolescents attending state and private schools. Community Dent Health. 2006; 23(4): 251-3.

29. Pinto A, Kim S, Wadenya R, Rosenberg H. Is there an association between weight and dental caries among pediatric patients in an urban dental school? A correlation study. J Dent Educ. 2007; 71(11): 1435-40.

30. Willerhausen B, Blettner M, Kasaj A, Hohenfellner K. Association between body mass index and dental health in 1,290 children of elementary schools in a German city. Clin Oral Investig. 2007; 11(3): 195-200.

31. Sakeenabi B, Swamy HS, Mohammed RN. Association between obesity, dental caries and socioeconomic status in 6- and 13-year-old school children. Oral Health Prev Dent. 2012; 10(3): 231-41.

32. Costacurta M, DiRenzo L, Sicuro L, Gratteri S, De Lorenzo A, Docimo R. Dental caries and childhood obesity: analysis of food intakes, lifestyle. Eur J Paediatr Dent. 2014;15(4): 343-8. 
33. Panwar NK, Mohan A, Arora R, Gupta A, Marya CM, Dhingra S. Study on relationship between the nutritional status and dental caries in 8-12 year old children of Udaipur City, India. Kathmandu Univ Med J (KUMJ). 2014; 12(45): 26-31.

34. Liang JJ, Zhang ZQ, Chen YJ, Mai JC, Ma J, Yang WH, Jing J. Dental caries is negatively correlated with body mass index among 7-9 years old children in Guangzhou, China. BMC Public Health. 2016; 16:638.

35. World Health Organization (1997). Oral Health Surveys: basic methods. $4^{\text {th }}$ ed. Geneva: World Health Organization 1997.

36. Abanto J, Carvalho TS, Mendes FM, Wanderley MT, Bönecker M, Raggio DP. Impact of oral diseases and disorders on oral health-related quality of life of preschool children. Community Dent Oral Epidemiol. 2011; 39(2): 105-14.

37. Krisdapong S, Somkotra T, Kueakulpipat W. Disparities in early childhood caries and its impact on oral health-related quality of life of preschool children. Asia Pac J Public Health. 2014; 26(3): 285-94.

38. Khanh LN, Ivey SL, Sokal-Gutierrez K, Barkan H, Ngo KM, Hoang HT, Vuong I, Thai N. Early Childhood Caries, Mouth Pain, and Nutritional Threats in Vietnam. Am J Public Health. 2015; 105(12): 2510-7.

39. Cypriano S, de Sousa Mda L, Wada RS. Evaluation of simplified DMFT indices in epidemiological surveys of dental caries. Rev Saude Publica. 2005; 39(2): 285-92.

40. Cypriano S, Hoffmann RH, de Sousa Mda L, Wada RS. Dental caries experience in 12-year-old schoolchildren in southeastern Brazil. J Appl Oral Sci. 2008; 16(4): 286-92.

41. US Department of Health and Human Services. National Center for Health Statistics. Clinical growth charts. BMI for age, ages 2-20 males and female. Public use date files. Available at: http://www.cdc.gov/growthcharts/clinical_ charts.htm. Accessed February 21, 2016.

42. Granville-Garcia AF, de Menezes VA, de Lira PI, Ferreira JM, Leite-Cavalcanti A. Obesity and dental caries among preschool children in Brazil. Rev Salud Publica (Bogota). 2008; 10(5): 788-95.

43. Hong L, Ahmed A, McCunniff M, Overman P, Mathew M. Obesity and dental caries in children aged 2-6 years in the United States: National Health and Nutrition Examination Survey 1999-2002. J Public Health Dent 2008; 68 (4): 227-33.
44. Quadri FA, Hendriyani H, Pramono A, Jafer M. Knowledge, attitudes and practices of sweet food and beverage consumption and its association with dental caries among schoolchildren in Jazan, Saudi Arabia. East Mediterr Health J. 2015; 21(6): 403-11.

45. Farooqi FA, Khabeer A, Moheet IA, Khan SQ, Farooq I, ArRejaie AS. Prevalence of dental caries in primary and permanent teeth and its relation with tooth brushing habits among schoolchildren in Eastern Saudi Arabia. Saudi Med J. 2015; 36(6): 737-42.

46. Aggeryd T. Goals for oral health in the year 2000: cooperation between WHO, FDI and the national dental associations. Int Dent J. 1983; 33(1): 55-9.

47. Wyne AH, Al-Ghorabi BM, Al-Asiri YA, Khan NB. Caries prevalence in Saudi primary schoolchildren of Riyadh and their teachers' oral health knowledge, attitude and practices. Saudi Med J. 2002; 23(1): 77-81.

48. Hayden C, Bowler JO, Chambers S, Freeman R, Humphris G, Richards D, et al. Obesity and dental caries in children: a systematic review and meta-analysis. Community Dent Oral Epidemiol 2013; 41 (4): 289-308.

49. Kopycka-Kedzierawski DT, Auinger P, Billings RJ, Weitzman M. Caries status and overweight in 2- to 18-year-old US children: findings from national surveys. Community Dent Oral Epidemiol. 2008; 36 (2): 157-67.

50. Clarke M, Locker D, Berall G, Pencharz P, KennDJy, Judd P. Malnourishment in a population of young children with severe early childhood caries. Pediatric Dentistry 2006; 28(3): 254-9.

51. Gaur S, Nayak R. Underweight in low socioeconomic status preschool children with severe early childhood caries. Journal of Indian Society of pedodontics and preventive dentistry. 2011; 29(4): 305-9.

52. Sadeghi M, Lynch CD, Arsalan A. Is there a correlation between dental caries and body mass index-for-age among adolescents in Iran? Community Dent Health. 2011; 28(2): 174-7.

53. Edalat A, Abbaszadeh M, Eesvandi M, Heidari A. The Relationship of Severe Early Childhood Caries and Body Mass Index in a Group of 3- to 6-year-old Children in Shiraz. J Dent Shiraz Univ Med Sci. 2014; 15(2): 68-73.

54. Costa LC, Daher A, Queiroz MG. Early childhood caries and body mass index in young children from low Income Families. Int. J. Environ. Res. Public Health 2013;10: 867-878. 
55. El Mouzan MI, Foster PJ, Al Herbish AS, Al Salloum AA, Al Omar AA, Qurachi MM. Prevalence of malnutrition in Saudi children: a community-based study. Ann Saudi Med. 2010; 30(5): 381-5.

56. Sheiham A. Dental caries affects body weight, growth and quality of life in pre-school children. Br Dent J. 2006; 201(10): 625-6.

57. Acs G, Lodolini G, Kaminski S, Cisneros GJ. Effect of nursing caries on body weight in a pediatric population. Pediatr Dent 1992; 14: 302-5.
58. Ayhan H, Suskan E, Yildirim S. The effect of nursing or rampant caries on height, body weight and head circumference. J Clin Pediatr Dent 1996; 20:209-12.

59. Means RT. Recent developments in the anemia of chronic disease. Curr Hematol Rep. 2003; 2:116-21.

60. Bhoomika W. Ramakrishna Y. Munshi AK. Relationship between severe early childhood caries and body mass index. The Journal of Clinical Pediatric Dentistry 2013; 37(3): 235-42. 